\title{
Health system innovations: adapting to rapid change
}

\author{
Gerald Bloom $^{1 *}$ D, Annie Wilkinson ${ }^{1}$ and Abbas Bhuiya ${ }^{2}$
}

\begin{abstract}
This paper introduces the Thematic Issue on Innovation in Health Systems in Low- and Middle-Income Countries.

Keywords: Technological innovation, Organizational innovation, Change management, Universal health coverage, Low and middle-income countries
\end{abstract}

A fundamental challenge for health systems is the need to adapt to changes in the patterns of health service need, scientific and technological developments, and the economic and institutional contexts within which providers of health services are embedded. This is especially true of many low and middle-income countries, where the pace of multiple and interconnected changes is breath-taking [1]. At a major meeting of UHC2030 in Tokyo in December 2017 several leaders in global health emphasized the potential role of technological innovations in making progress towards universal health coverage.

There is a growing body of literature on health systems innovation. A Web of Science search for "innovation" and "health systems" returned 54 results in 1999-2000, 86 in 2004-5, 159 in 2009-10 and 187 in 2014-15. In recent years there has been a very rapid increase in investment in innovations by bilateral donor agencies and health foundations. A major emphasis of this investment has been on relatively small-scale pilot projects aimed at a proof of an innovative technological or organizational concept. The outcomes, in terms of health system change or improved health outcomes have tended to be disappointing. This has led to calls for a systems (or systematic) approach towards stimulating the emergence and diffusion of innovations at scale.

Despite the growing interest in the potential contributions that a number of innovations can make towards improving access to health services, the dominant conceptualizations of health system development have

* Correspondence: G.Bloom@ids.ac.uk

${ }^{1}$ Institute of Development Studies, University of Sussex, Brighton BN1 9RE, UK Full list of author information is available at the end of the article tended to focus on the different "pillars" of a health system, while paying relatively little attention to the consequences for these systems of rapid change. However, new thinking is emerging. A number of publications now describe the health sector as a complex adaptive system and the focus of so-called "implementation research" is on the process of change, rather than the specific design of a particular intervention [2]. Others are exploring long-term historical processes of health system development. A notable example is a recent special issue of The Lancet [3] with a number of papers analyzing the management of health system innovation in Bangladesh over more than three decades.

The purpose of this thematic issue is to stimulate analyses of innovation in the context of complex and dynamic health systems. Although the focus is on low and middle-income countries, the papers have a wider geographic relevance. A number of rapidly growing low and middle-income countries are becoming global centers of technological and organizational innovation. The governments of these countries are under growing pressure to meet the health and health care needs of very large numbers of people whose incomes are rising above the poverty line and the innovations that emerge will soon have global impact. The expertise that governments of these countries are developing in the management of rapid change has important lessons for all governments.

The initial papers in this thematic issue present the findings of research by members of the Future Health Systems Consortium. It soon became clear that other researchers have been thinking along complementary lines. Members of the thematic working group on the private sector of Health Systems Global, an international 
network of health system researchers, offered to join the editorial team and we have decided to open the thematic issue to other papers relevant to the theme. We invite authors of papers to submit them for consideration by the thematic issue. And, we encourage people interested in this topic to participate in the work of the thematic working group by contacting us at psinhealth@gmail.com

\section{Acknowledgements}

The authors would like to thank the authors of the papers in this collection and to the reviewers, who have provided excellent and constructive comments. They would also like to thank the researchers in the Future Health Systems Consortium for many stimulating discussions, over the years, on the topic of this thematic issue.

\section{Funding}

The Future Health Systems Consortium (http://www.futurehealthsystems.org), which is funded by UK Aid from the UK Government.

Availability of data and materials

Not applicable.

\section{Authors' contributions}

GB produced a first draft, $A W$ and $A B$ made revisions and all authors read and approved the final manuscript.

\section{Authors' information}

Not applicable.

Ethical approval and consent to participate

Not applicable.

\section{Consent for publication}

Not applicable.

\section{Competing interests}

The authors declare that they have no competing interests.

\section{Publisher's Note}

Springer Nature remains neutral with regard to jurisdictional claims in published maps and institutional affiliations.

\section{Author details}

'Institute of Development Studies, University of Sussex, Brighton BN1 9RE,

UK. ${ }^{2} \mathrm{I} d d \mathrm{~d}, \mathrm{~b}$, Dhaka, Bangladesh.

Received: 16 February 2018 Accepted: 27 February 2018

Published online: 09 March 2018

\section{References}

1. Bloom G, Wolcott S. Building institutions for health and health Systems in Contexts of rapid change. Soc Sci Med. 2013;96:216-22.

2. Peters D, Adam T, Alonge O, Agyepong I, Tran N. Implementation research: what it is and how to do it. Br Med J. 2013;347:f6753.

3. The Lancet (2013) Bangladesh: Innovation for Universal Health Coverage November 2013.

Submit your next manuscript to BioMed Central and we will help you at every step:

- We accept pre-submission inquiries

- Our selector tool helps you to find the most relevant journal

- We provide round the clock customer support

- Convenient online submission

- Thorough peer review

- Inclusion in PubMed and all major indexing services

- Maximum visibility for your research

Submit your manuscript at www.biomedcentral.com/submit 